\title{
STEP Report on Advanced ODS FeCrAl Alloys for Fission Applications
}

\section{Nuclear Technology}

Research and Development

\author{
Prepared for \\ U.S. Department of Energy \\ Advanced Fuels Campaign \\ Caleb P. Massey, \\ Ty. Austin, \\ Sebastien N. Dryepondt, \\ Kory D. Linton, \\ Andrew T. Nelson \\ Oak Ridge National Laboratory \\ September 25, 2020 \\ M3FT-20OR020202064
}




\section{DISCLAIMER}

This information was prepared as an account of work sponsored by an agency of the U.S. Government. Neither the U.S. Government nor any agency thereof, nor any of their employees, makes any warranty, expressed or implied, or assumes any legal liability or responsibility for the accuracy, completeness, or usefulness, of any information, apparatus, product, or process disclosed, or represents that its use would not infringe privately owned rights. References herein to any specific commercial product, process, or service by trade name, trade mark, manufacturer, or otherwise, does not necessarily constitute or imply its endorsement, recommendation, or favoring by the U.S. Government or any agency thereof. The views and opinions of authors expressed herein do not necessarily state or reflect those of the U.S. Government or any agency thereof. 
This page is intentionally left blank. 


\section{CONTENTS}

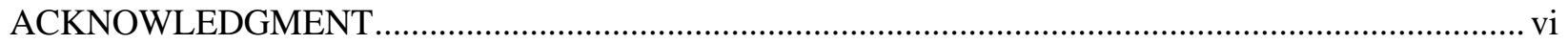

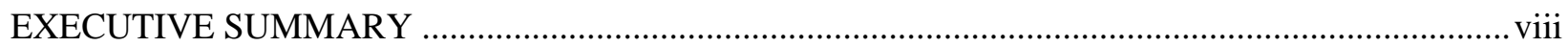

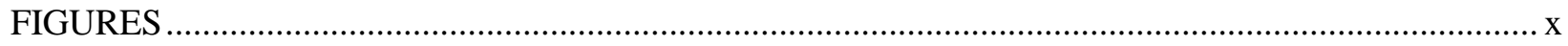

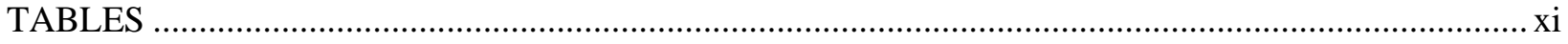

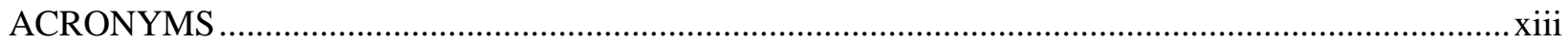

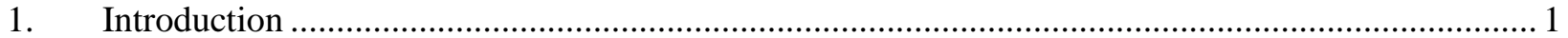

2. Insights from FY20 Characterization of Two New ODS FeCrAl Tubes with Varying

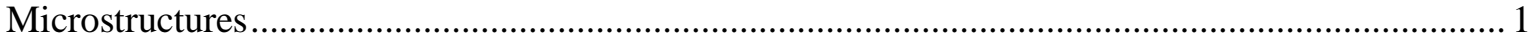

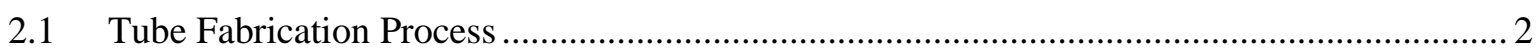

2.2 Microstructure-Mechanical Property Correlations............................................................. 6

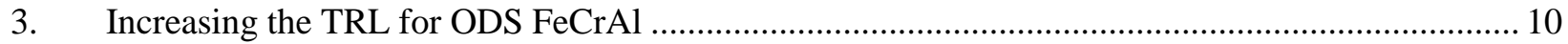



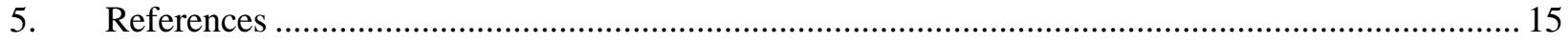


This page is intentionally left blank. 


\section{ACKNOWLEDGMENT}

This research was sponsored by the US Department of Energy Office of Nuclear Energy's Advanced Fuels Campaign Program under contract DE-AC05-00OR22725 with UT-Battelle LLC.

The authors are grateful for Eric Manneschmidt and Xiang (Frank) Chen from Oak Ridge National Laboratory for access to mechanical testing equipment for tube tensile property evaluations. The authors also appreciate Jonathan Poplawsky and James Burns for their help in acquiring the atom probe tomography data shown in this work. Lastly, the authors thank David Hoelzer and TS Byun for their thoughtful reviews of this report before publication. 
This page is intentionally left blank. 


\section{EXECUTIVE SUMMARY}

Oak Ridge National Laboratory is developing advanced low-Cr oxide dispersion strengthened (ODS) FeCrAl alloys for accident tolerant fuel (ATF) cladding. This report presents the characterization of two new ODS FeCrAl tubes by using powder commercially mechanically alloyed by Zoz GmbH, which underwent high-precision tube rolling with two different annealing schedules. This work shows that the ODS FeCrAl tube without recrystallization exhibits consistent mechanical behavior in comparison with a previously produced tube. The second tube, which underwent a full recrystallization step before the final tube rolling step, showed some circumferential cracking and exhibited limited ductility in the axial tube tensile tests. Based on current and prior work on the ODS FeCrAl alloy system, this report compares the current state of the scientific literature on the alloy class with that of wrought $\mathrm{FeCrAl}$ without oxide additions. Then, this report makes recommendations for future research directions that should be undertaken to increase the technology readiness level for ODS FeCrAl as a viable ATF candidate material.

This report has been submitted as fulfillment of milestone M3FT-20OR020202064 titled, "STEP Report on Advanced ODS FeCrAl Alloys for Fission Applications" for the US Department of Energy Office of Nuclear Energy's Advanced Fuel Campaign of the Fuel Cycle R\&D program. 
This page is intentionally left blank. 


\section{FIGURES}

Figure 1. Microhardness evolution of the three ODS FeCrAl tubes fabricated to date as a function of thermomechanical processing steps.

Figure 2. Scanning electron images across the wall thickness of an ODS FeCrAl specimen following the second pilgering step and various thermal annealing treatments. As the annealing temperature increases from $850-1,000^{\circ} \mathrm{C}$, larger area fractions are occupied by recrystallized grains, and $850^{\circ} \mathrm{C}$ was selected as temperature for tube annealing.

Figure 3. Example of microhardness variation in an ODS FeCrAl tube following the third pilgering step, annealed at increasing temperatures from $850-1,300^{\circ} \mathrm{C}$. The figure shows point histograms and box plots that summarize the data at each annealing treatment.

Figure 4. Photos of as-received CrAZY Z6 (top) and Z7 (bottom), following the final pilgering step. Multiple circumferential cracks are noticeable in the $\mathrm{Z7}$ tube subjected to a full recrystallization anneal before the final pilgering step.

Figure 5. EBSD data for CrAZY Tube Z6. The (a) FSD and (b) band contrast images show the submicron grain structure, and the corresponding inverse pole figure maps highlight the orientation of each grain with respect to directions parallel to the (c) normal direction and (d) rolling direction.

Figure 6. EBSD data for CrAZY Tube Z7. The (a) FSD and (b) band contrast images show very large grains with significant intragranular deformation bands. Corresponding inverse pole figure maps highlight the orientation of each grain with respect to directions parallel to the (c) normal direction and (d) rolling direction.

Figure 7. Atom probe tomography analysis confirms that the precipitates within $\mathrm{Z} 6$ and $\mathrm{Z7}$ are enriched in $\mathrm{Y}, \mathrm{Al}$, and $\mathrm{O}$. Isosurfaces (left) use a concentration threshold of 3 at.\% (Y, $\mathrm{Al}, \mathrm{O}$ ) atop black dots that represent $0.5 \%$ of matrix $\mathrm{Fe}$ atoms. 8

Figure 8. Graphical summaries of nanoprecipitate size distributions in the Z6 and Z7 tubes, following tube processing. The higher annealing temperature used to fully recrystallize the $\mathrm{Z} 7$ tube, $1,200^{\circ} \mathrm{C}$, shifted the size distribution to larger precipitate radii in comparison with Z6 due to precipitate coarsening.

Figure 9. Axial tube tensile tests directly compare the original pilgered CrAZY-OR1 tube with the properties of the two new CrAZY tubes (Z6 and Z7). On the left, the experimental setup for the tube tensile test is provided, and on the right, engineering stress/strain curves at room temperature are overlaid for each tube.

Figure 10. Visual representation of significant milestone achievements for ODS FeCrAl alloy development as a function of time (blue) in comparison with the equivalent TRL outlined in Table 5. 


\section{TABLES}

Table 1. Master rod processing parameters for the OR-series and Z-series CrAZY alloys........................2

Table 2. Composition of the CrAZY rod/tube variants in wt.\% ......................................................... 3

Table 3. A selection of work to date on ODS FeCrAl in comparison with benchmarks from the previous technology implementation plan.

Table 4. Summary of prior milestone reports submitted in the ODS FeCrAl program...........................12

Table 5. Summary of TRLs pertaining to the ODS FeCrAl system. 
This page is intentionally left blank. 


\title{
ACRONYMS
}

\author{
ATF accident tolerant fuel \\ CR cold rolling \\ EBSD electron backscatter diffraction \\ FSD forward scattering detector \\ INL Idaho National Laboratory \\ LAMDA Low Activation Materials Development and Analysis laboratory \\ LOCA loss-of-coolant analysis \\ LTR lead test rod \\ ODS oxide dispersion strengthened \\ ORNL Oak Ridge National Laboratory \\ PWR pressure resistance welding \\ RIA reactivity-initiated accident \\ TRL technology readiness level
}


This page is intentionally left blank. 


\section{STEP REPORT ON ADVANCED ODS FECRAL ALLOYS FOR FISSION APPLICATIONS}

\section{Introduction}

After the Fukushima Daiichi accident in 2011, extensive research was conducted to develop new accident tolerant fuel (ATF) cladding materials that serve as drop-in replacements for existing Zr-based cladding to help mitigate nuclear accident scenarios, enhance reactor safety, and extend reactor lifetimes $[1,2]$. Initial alloy development efforts at Oak Ridge National Laboratory (ORNL) focused on selecting materials that could withstand steam oxidation at elevated temperatures, which led to the development of low-Cr nuclear-grade $\mathrm{FeCrAl}$ alloys with $\mathrm{Y}$ additions for this purpose [3-7].

In addition to the effort of developing wrought $\mathrm{FeCrAl}$ alloys, research was conducted on similar low-Cr $\mathrm{FeCrAl}$ variants with oxide particle dispersions, which are called oxide dispersion strengthened (ODS) FeCrAl alloys [8-14]. The main goal of this initiative was to build on the high-temperature oxidation resistance of the Al-added ferritic alloy while simultaneously improving high-temperature strength and irradiation resistance by embedding many density of complex ternary oxides ( $2-4 \mathrm{~nm})$ throughout the microstructure. The many interfaces would serve as sinks for irradiation-induced defects and reduce irradiation hardening in normal light water reactor-operating temperature regimes. Additionally, these precipitates would simultaneously serve as obstacles for dislocation motion within the microstructure, thereby increasing strength, creep properties, and burst properties at high temperatures because the burst properties of the ferritic $\mathrm{FeCrAl}$ alloy are dominated by the onset of plastic instability — and thus the ultimate tensile strength of the material—during accident scenarios [15].

In May 2015, a technology implementation plan was developed for the FeCrAl system, which served as the backdrop for wrought and ODS FeCrAl development for the next half decade [16]. This report reviews the current status of the ODS FeCrAl program through the lens of prior work and new results from FY20 research. Then, future research directions are recommended for the ODS FeCrAl program with a specific aim to increase the technology readiness level (TRL) of the concept.

\section{Insights from FY20 Characterization of Two New ODS FeCrAl Tubes with Varying Microstructures}

As outlined in prior published works, the optimized chemical composition based on alloy oxidation and mechanical property evolutions was refined to an ODS FeCrAl alloy containing Fe-10/12Cr-6Al$0.3 \mathrm{Zr}+0.3 \mathrm{Y}_{2} \mathrm{O}_{3}$ (referred to as $\mathrm{CrAZY}$ for the remainder of this work) [8-14]. Additionally, previous evaluations of the effect of mechanical alloying time and extrusion temperature illustrated the need for careful control of these parameters to ensure sufficient strength and ductility without substantial particle coarsening within the alloy microstructure [13, 14]. Through a collaboration with Nippon Nuclear Fuel Development Co. Ltd., a previously extruded master rod of the CrAZY ODS alloy was pilgered successfully into a thin-walled tube measuring $1.8 \mathrm{~m}$ long with a tube outer diameter and thickness of $8.5 \mathrm{~mm}$ and $0.5 \mathrm{~mm}$, respectively [9]. In this work, two new thin-walled ODS FeCrAl tubes were produced by using two different thermomechanical processing routes to boiling water reactor-relevant dimensions. One tube was fabricated by using similar annealing treatments used previously for the initial successful CrAZY tube [9], and a modified annealing treatment was used on the other to investigate how fabricability changes with grain structure. 


\subsection{Tube Fabrication Process}

The CrAZY tubes presented in this work (heat designations Z6 and Z7, respectively) were fabricated by using the same powder metallurgical route as the original CrAZY tube (heat designation OR1). Five mechanical alloying runs were performed under Ar atmosphere with $3 \mathrm{~kg}$ batches of $\mathrm{Fe}-12 \mathrm{Cr}-6.1 \mathrm{Al}-$ $0.3 \mathrm{Zr}+0.3 \mathrm{Y} 2 \mathrm{O} 3$ (126ZY) powder supplied as a mixture of gas atomized FeCrAlZr powder acquired from ATI Powder Metals and nanocrystalline yttria from Alfa Aesar. Milling was performed by Zoz GmbH with a larger CM20 Simoloyer milling unit at rotational speeds of 230 RPM/394 RPM in cycles of 9 and 3 minutes, respectively, for a total of 40 hours. As-milled powder was kept in an Ar atmosphere during removal from the unit and shipped back to ORNL. As-received 126ZY powder was packed into 4 in. mild steel extrusion cans under Ar by using a glove box to minimize contact with air. Powder was packed in an identical manner to prior powder packing methodologies previously performed in air whereby powder was poured into the extrusion cans and then agitated to maximize powder packing into each can. Cans were welded and subjected to a degassing step at $10^{-6}$ Torr by using a diffusion pump for 24 hours at $300^{\circ} \mathrm{C}$. Each can was annealed for 2 hours at $950^{\circ} \mathrm{C}$ in a box furnace, followed by immediate transfer to a second box furnace held at $1,050^{\circ} \mathrm{C}$ for 1 hour and then subsequent extrusion. These parameters were chosen to (1) allow for a homogeneous sample temperature of $950^{\circ} \mathrm{C}$ for nanoprecipitate nucleation and growth and (2) minimize precipitate coarsening at the $1,050^{\circ} \mathrm{C}$ temperature based on previously developed particle coarsening models [14].

There are a few differences between the two tubes presented here (Z6 and Z7) and the previous tube (OR1), as presented in Table 1 and Table 2. First, the compositions are slightly different; the Cr content was increased from 10-12 wt.\% to provide more effective oxidation resistance. Additionally, the powder used for the Z6 and Z7 alloys was ball milled by the commercial vendor Zoz GmbH in a larger Simoloyer unit with a $3 \mathrm{~kg}$ powder capacity. This is in comparison with the Simoloyer CM08 unit with a $1 \mathrm{~kg}$ powder capacity at ORNL. The milling times remained the same, and rotation speeds were adjusted to ensure equivalent energy deposition to the milled powders by the milling media. For the Z6 and Z7 tubes, the powder was kept under Ar until welded inside the extrusion cans, whereas for the OR1, powder transfer from the ball mill machine to the extrusion can was performed in air. The last difference between the Z6 and Z7 extrusion was the use of different pre- and post-extrusion annealing conditions to better optimize the precipitate distribution and hardness.

Table 1. Master rod processing parameters for the OR-series and Z-series CrAZY alloys.

\begin{tabular}{|c|c|c|}
\hline CrAZY alloy & OR1 & Z6/Z7 \\
\hline Powder vendor & ATI & ATI \\
Mechanical alloying vendor & N/A (ORNL) & Zoz GmbH \\
Ball-mill used & Zoz Simoloyer CM08-8lm & Zoz Simoloyer CM20-20lm \\
Milling time (hours) & 40 & 40 \\
Milling speeds (RPM) & $350 / 600$ & $230 / 395$ \\
Time at speed (minutes) & $9 / 3$ & $9 / 3$ \\
Powder produced (kg) & 2 & 15 \\
Milling atmosphere & $\mathrm{Ar}$ & $\mathrm{Ar}$ \\
Extrusion can size & $4 \mathrm{in.} \mathrm{OD}$ & $4 \mathrm{in} . \mathrm{OD}$ \\
Degassing & 24 hours at $300^{\circ} \mathrm{C}$ & $24 \mathrm{hours} \mathrm{at} 300^{\circ} \mathrm{C}$ \\
Pre-extrusion anneal & $1,100^{\circ} \mathrm{C} / 1$ hour & $950^{\circ} \mathrm{C} / 2$ hours $+1,050^{\circ} \mathrm{C} / 1$ hour \\
Post-extrusion anneal & $1,000^{\circ} \mathrm{C} / 5$ hours & N/A \\
\hline
\end{tabular}


Table 2. Composition of the CrAZY rod/tube variants in wt.\%.

\begin{tabular}{|c|cccccccc|}
\hline ID & Fe & Cr & Al & Zr & Y & C & N & O \\
\hline CrAZY-OR1 & 83.46 & 9.71 & 6.03 & 0.27 & 0.22 & 690 & 171 & 1140 \\
\hline CrAZY-Z6/Z7 & 81.71 & 11.56 & 6.01 & 0.30 & 0.28 & 230 & 140 & 2500 \\
\hline
\end{tabular}

Once the master rods were precision gun-drilled into $2 \mathrm{~mm}$ thick-walled tubes, they underwent four highprecision tube cold rolling (CR) passes to a total reduction of wall thickness greater than $80 \%$, as shown in Figure 1. In this figure, the solid black line indicates the former evolution in microhardness for the initial CrAZY-OR1 tube as a function of processing step, and the red dashed line indicates the evolution of CrAZY-Z6 and CrAZY-Z7. After the third rolling step, the dashed line changes to either blue (CrAZYZ6) or purple (CrAZY-Z7) because the annealing step differed at this point between the two tubes. After each rolling step, there is a general trend in that as thickness is reduced, the material becomes harder, and then after the annealing treatment, the hardness drops. This decrease in hardness is due to dislocation recovery and is necessary to maintain the hardness below $400 \mathrm{HV}$, the targeted limit based on the tube producer input. The temperature for each intermediate annealing step is called out for each alloy in their respective color in the figure. The selection of the intermediate annealing treatment was informed by targeted annealing treatments on small sections of the ends of each tube at each processing step followed by a scanning electron microscopy investigation to see whether any grain recrystallization or growth occurred. Generally, the annealing treatment desired was one that induced recovery but not recrystallization, so when appreciable recrystallization and grain growth started to be visible, the temperature below this point was chosen as the desired annealing temperature, as shown in Figure 2.

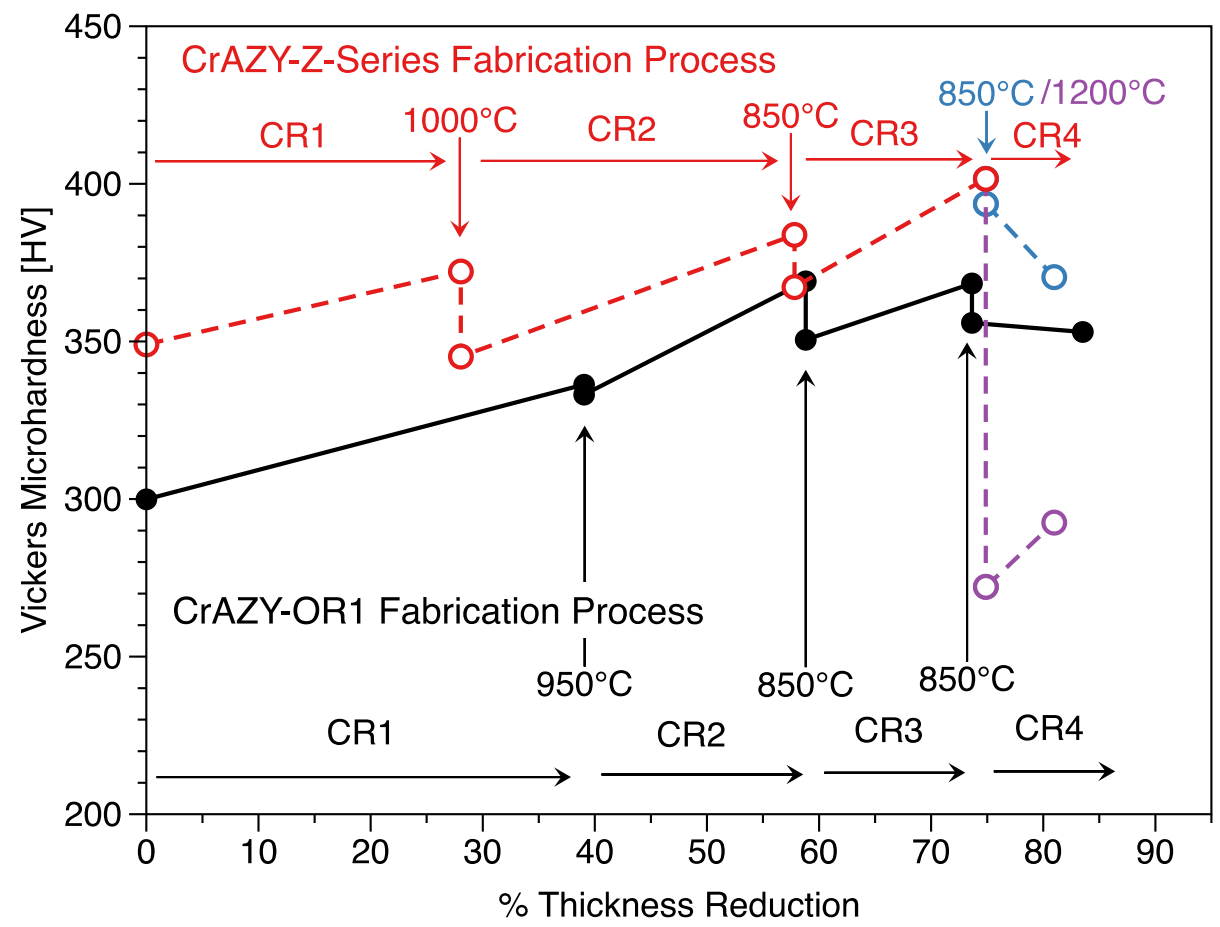

Figure 1. Microhardness evolution of the three ODS FeCrAl tubes fabricated to date as a function of thermomechanical processing steps. 


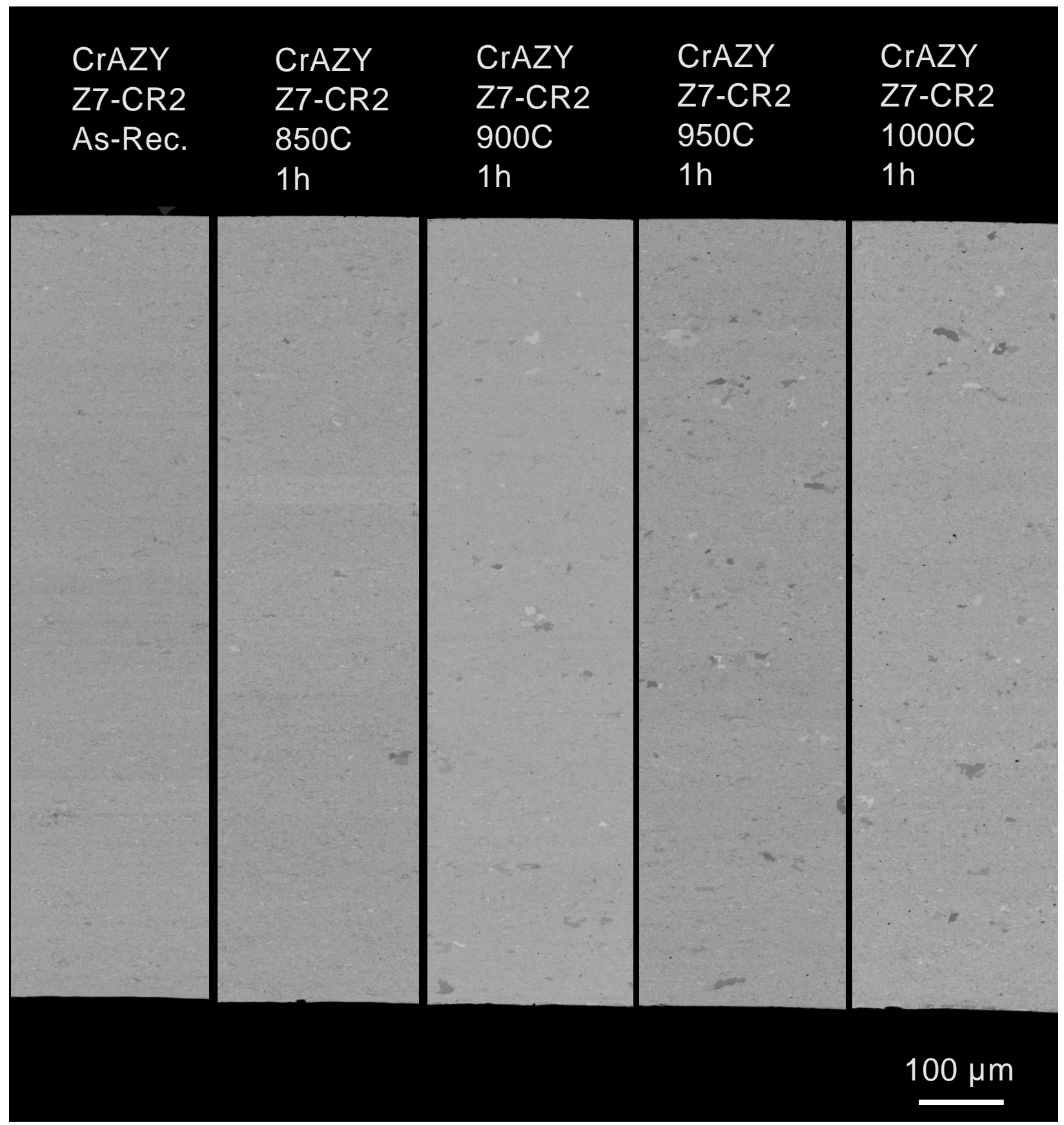

Figure 2. Scanning electron images across the wall thickness of an ODS FeCrAl specimen following the second pilgering step and various thermal annealing treatments. As the annealing temperature increases from $850-1,000^{\circ} \mathrm{C}$, larger area fractions are occupied by recrystallized grains, and $850^{\circ} \mathrm{C}$ was selected as temperature for tube annealing 
As highlighted in Figure 1, the annealing treatments diverged for CrAZY Z6 and Z7 after the third high precision tube rolling step. For the Z6 tube, it was desired to create a comparable tube to OR1 to demonstrate consistency in tube production. For Z7, it was of interest to see whether higher ductility could be accomplished through full recrystallization followed by some additional deformation. Fully recrystallized ODS FeCrAl alloys were recently demonstrated to have at least some ductility and attractive high-temperature strength $[17,18]$. However, full recrystallization reduces the yield and ultimate tensile strength appreciably due to the loss of essentially all Hall-Petch strengthening; thus, it was of interest in this work to see whether additional dislocations could be reintroduced into the microstructure via cold work to increase the dislocation strengthening of the microstructure since the dislocations would be easily pinned by existing oxide precipitates. To accomplish this task, microhardness measurements (Figure 3) were coupled with microscopy to evaluate when full recrystallization would occur after the third rolling step, which is indicated by the sudden drop in hardness at the $1,200^{\circ} \mathrm{C}$ annealing condition. The result was a recovered microstructure for $\mathrm{Z} 6$ and a fully recrystallized microstructure for $\mathrm{Z7}$ after the third CR.

Unfortunately, although effective at cold working the microstructure, the additional rolling step (CR4) resulted in the formation of circumferential cracks throughout the final Z7 tube (Figure 4). These cracks could be the result of a variety of factors, such as: (1) the lack of deformation modes for the abnormally large grains within the fully recrystallized microstructure, (2) the highly anisotropic stress state involved with tube rolling, and (3) the existence of larger carbides and nitrides that would have coarsened considerably during a $1,200^{\circ} \mathrm{C}$ annealing treatment. In comparison, the ultrafine-grained $\mathrm{Z} 6$ tube did not show any indication of cracking following the recovery anneal at $850^{\circ} \mathrm{C}$.

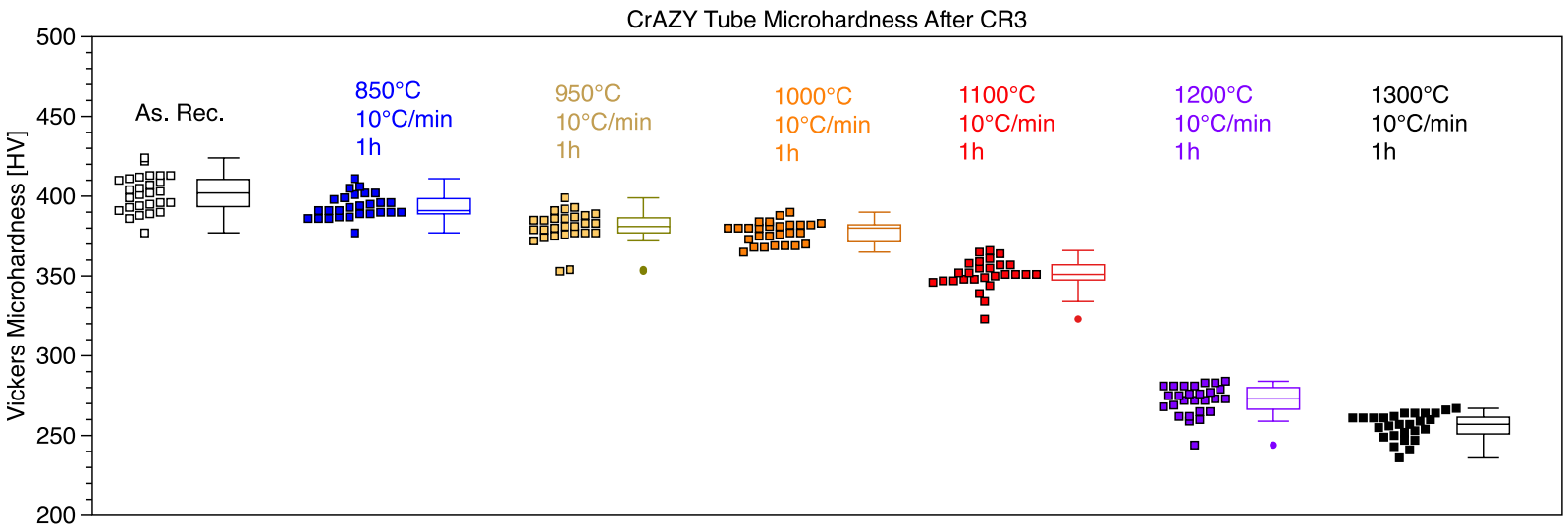

Figure 3. Example of microhardness variation in an ODS FeCrAl tube following the third pilgering step, annealed at increasing temperatures from $850-1,300^{\circ} \mathrm{C}$. The figure shows point histograms and box plots that summarize the data at each annealing treatment.

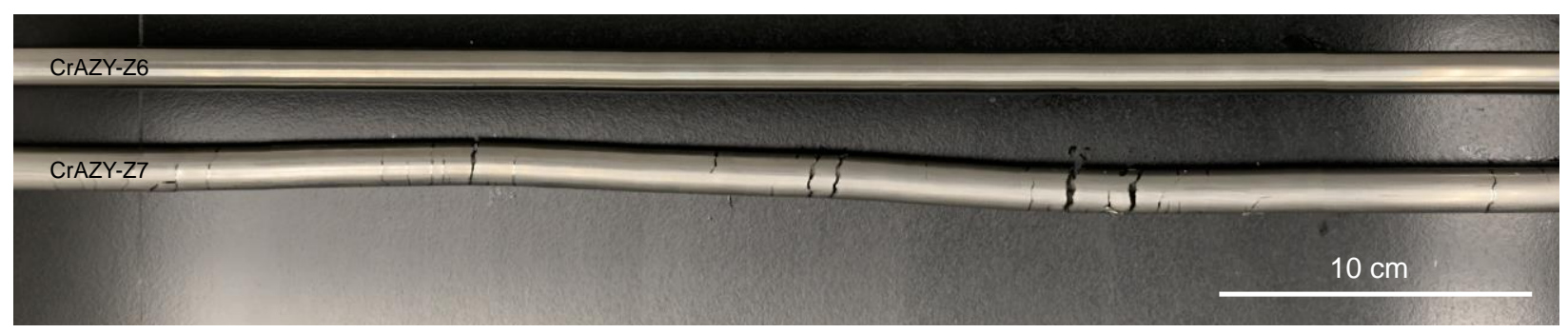

Figure 4. Photos of as-received CrAZY Z6 (top) and Z7 (bottom), following the final pilgering step. Multiple circumferential cracks are noticeable in the $\mathrm{Z} 7$ tube subjected to a full recrystallization anneal before the final pilgering step. 


\subsection{Microstructure-Mechanical Property Correlations}

A more detailed microstructure investigation shows significant similarity between the Z6 and OR1 tubes while highlighting the highly chaotic cold-worked microstructure for the $\mathrm{Z7}$ tube. Figure 5 highlights an identical microstructure for Z6 compared to what was previously reported for CrAZY-OR1 [19]. By coupling the forward scattering detector (FSD) image with the electron backscatter diffraction (EBSD) band contrast map, numerous nanometer-scale grains are identified, and elongated micron-sized grains with significant subgrain texture are also identified. All grains appear to be highly textured; perpendicular to the tube axis, there are strong [001] and [110] orientations (red and green colors, respectively), and parallel to the tube axis there are predominantly [110] orientations. This is consistent with alpha rolling fibers in body-centered cubic materials [20] and is identical to that previously seen for OR1. Conversely, the $\mathrm{Z} 7$ tube shows significant deformation across large grains, spanning hundreds of microns to millimeters in size (Figure 6). The large field-of-view ESBD image shown in Figure 5 spans the entire wall thickness of the cladding tube, and only four to five grains exist across the cladding thickness. However, the original grains are difficult to visualize since the entire field of view is filled with deformation bands ranging from 10 to 40 degrees in misorientation with respect to the surrounding grain structure.

In addition to changes associated with grain size, the higher temprature recrystallization heat treatment did coarsen the nanoscale (Y, Al, O)-rich precipitates within the CrAZY-Z7 alloy. This precipitate coarsening was captured by using atom probe tomography datasets, several of which are presented in Figure 7. In Figure 7, isoconcentration surfaces - surface boundaries delineating regions in which cumulative $\mathrm{Y}, \mathrm{Al}$, and $\mathrm{O}$ concentration exceeds 3 at.\% — clearly show the precipitates homogeneously distributed throughout the microstructures in Z6 and Z7, respectively. Additionally, atom maps for
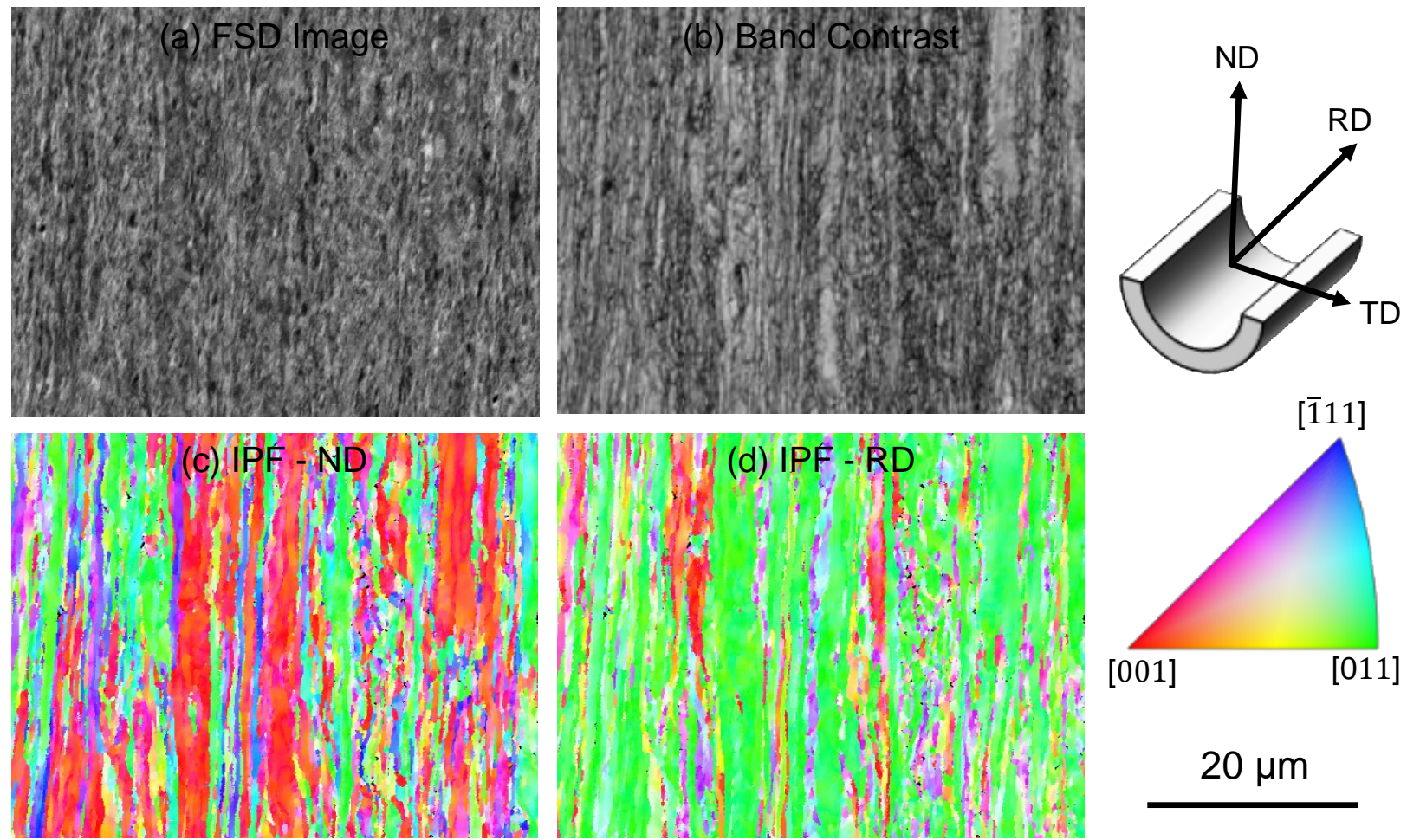

Figure 5. EBSD data for CrAZY Tube Z6. The (a) FSD and (b) band contrast images show the submicron grain structure, and the corresponding inverse pole figure maps highlight the orientation of each grain with respect to directions parallel to the (c) normal direction and (d) rolling direction. 
molecular ion species (Y, YO, AlO, and $\mathrm{Zr}$ ) are also shown to highlight which elemental species are within the precipitates (Y, Al, O) and which are not (i.e., Zr). This behavior is consistent with a recently published work that highlights the importance of $\mathrm{C}$ and $\mathrm{N}$ on the precipitation state in these CrAZY alloys [21], which is the main reason why the precipitation state in this alloy differs from that previously reported for similar FeCrAlZrY alloys developed elsewhere [22]. The additional 1,200 ${ }^{\circ} \mathrm{C}$ anneal required to recrystallize the $\mathrm{Z} 7$ microstructure coarsened the average precipitate diameter because the diameters for Z6 and Z7 were calculated to be 5.3 and $7.5 \mathrm{~nm}$, respectively. Additionally, the number density dropped from $2.1 \times 10^{23} \mathrm{~m}^{-3}$ to $2.7 \times 10^{22} \mathrm{~m}^{-3}$ after the anneal. Box plots and histograms for precipitate distributions in the CrAZY-Z6 and Z7 alloys are provided in Figure 8.

These microstructural changes due to recrystallization are important not only to the mechanical properties but also to the irradiation resistance of the tubes. The first of these two ramifications was investigated via axial tube tensile testing. By using a mechanical test frame and a strain rate of $10^{-3} \mathrm{~s}^{-1}$ at room temperature in the air, each specimen was tested to failure. A visual representation of the shoulder loaded axial tube specimen is provided in Figure 9 along with two stress-strain curves for the original CrAZY-OR1 tube, the $\mathrm{Z} 6$ tube, and the $\mathrm{Z7}$ tube. There was minimal sample-to-sample variation for each specimen condition. As shown in Figure 1, the total deformation experienced by the Z-series tubes was similar to that experienced originally by the CrAZY-OR1 alloy. The similarities in terms of microstructure and tensile properies between $\mathrm{Z} 6$ and OR1 highlight the good reproducbility of the tubes fabrication procedure. The more drastic changes pertain to the $\mathrm{Z7}$ alloy, which has approximately half the ultimate tensile strength ( $\sim 800 \mathrm{MPa})$ in comparison with the Z6/OR1 alloys ( 1,300 MPa). Interestingly, this lower yield strength for $\mathrm{Z7}$ does not result in higher ductility since the $\mathrm{Z} 6$ and $\mathrm{Z7}$ alloys showed approximately $5 \%$ uniform elongation before entering into a region of plastic instability and eventual failure. Improving tube ductility was one key reason for performing the recrystallization step. This lack of ductility for Z7 is likely attributed to the already saturated microstructure with significant defects due to the final CR4 step, as exemplified by the deformation band structure in Figure 6 .
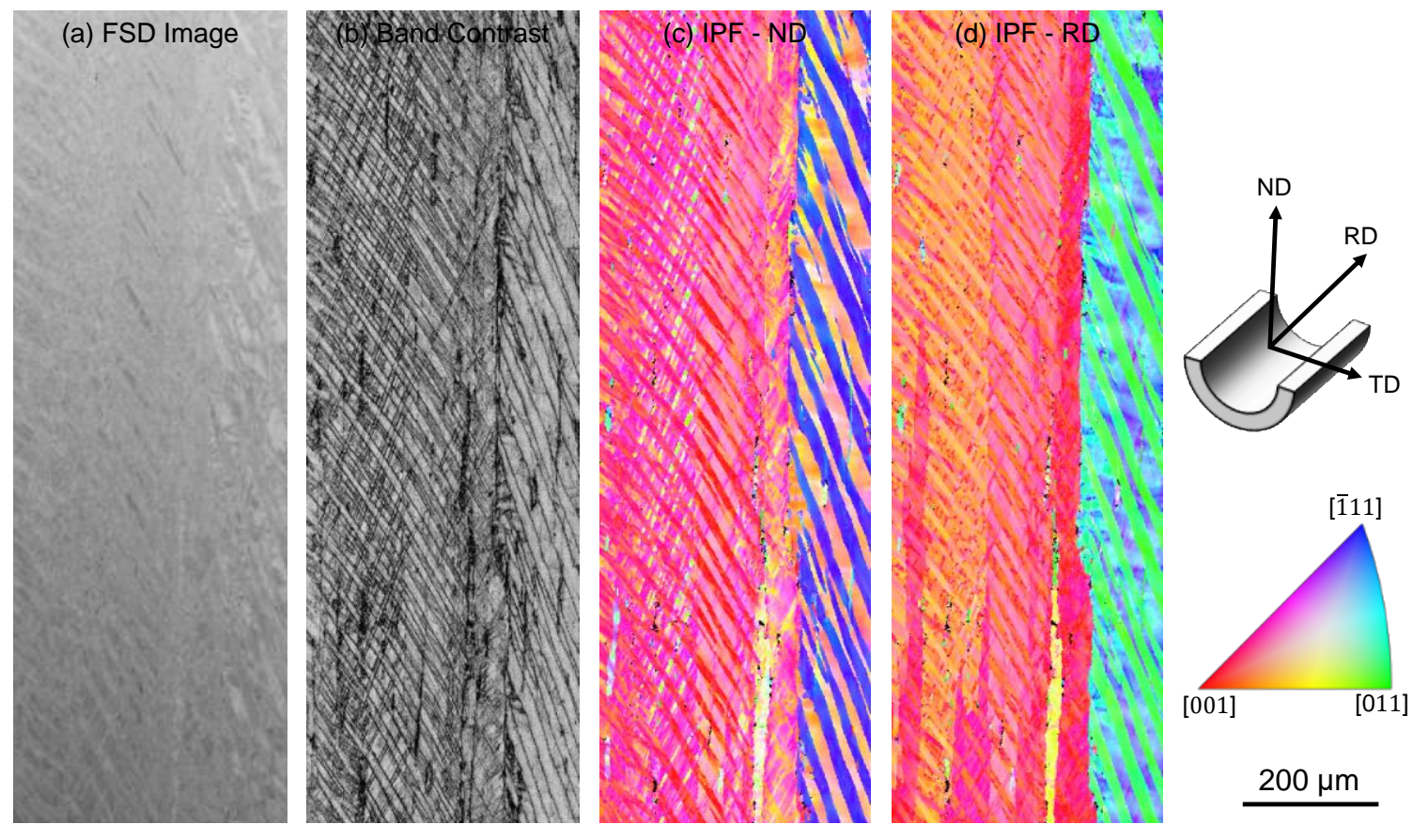

Figure 6. EBSD data for CrAZY Tube Z7. The (a) FSD and (b) band contrast images show very large grains with significant intragranular deformation bands. Corresponding inverse pole figure maps highlight the orientation of each grain with respect to directions parallel to the (c) normal direction and (d) rolling direction. 

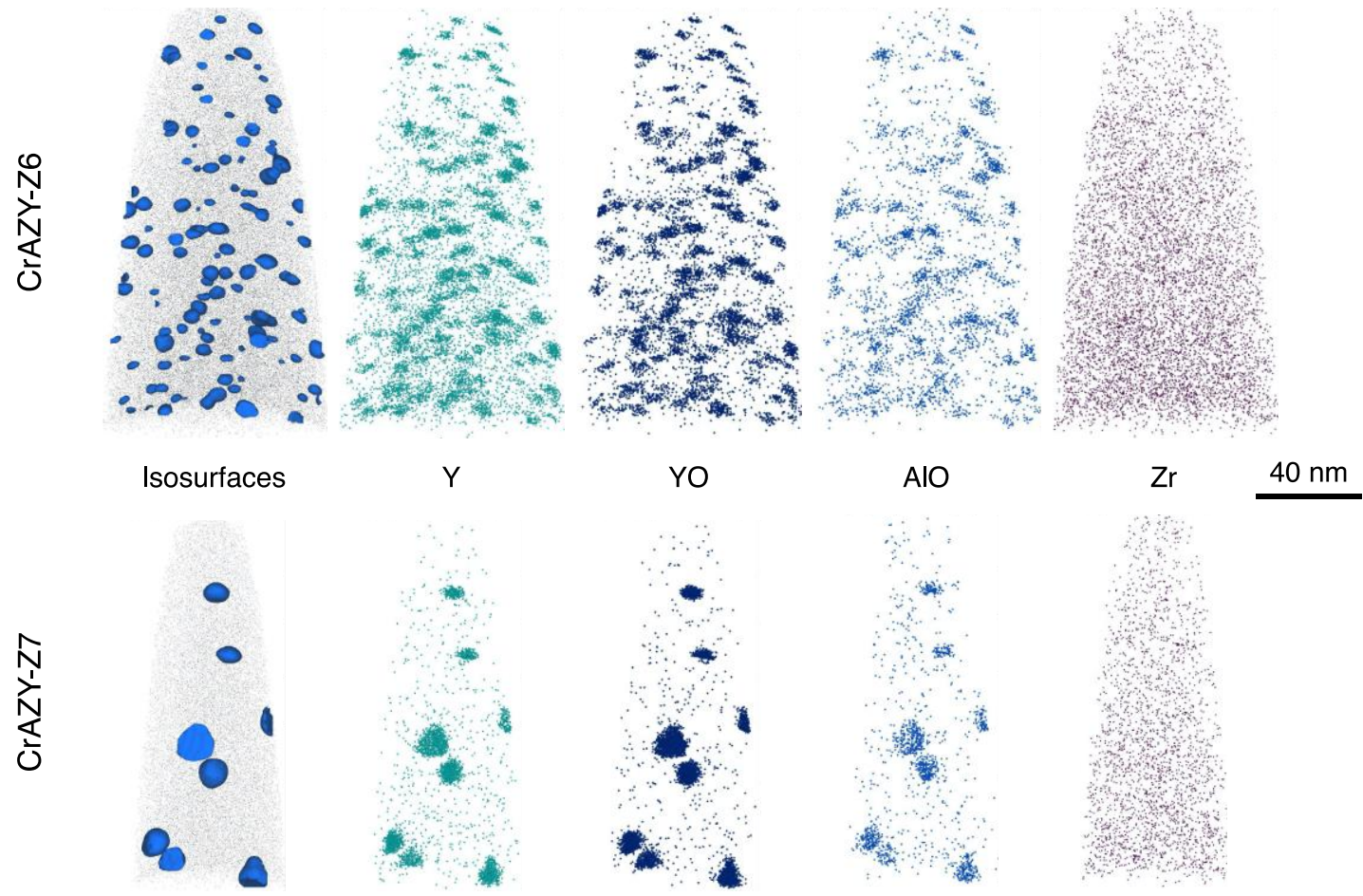

Figure 7. Atom probe tomography analysis confirms that the precipitates within Z6 and Z7 are enriched in $\mathrm{Y}, \mathrm{Al}$, and $\mathrm{O}$. Isosurfaces (left) use a concentration threshold of 3 at.\% $(\mathrm{Y}, \mathrm{Al}, \mathrm{O})$ atop black dots that represent $0.5 \%$ of matrix $\mathrm{Fe}$ atoms.

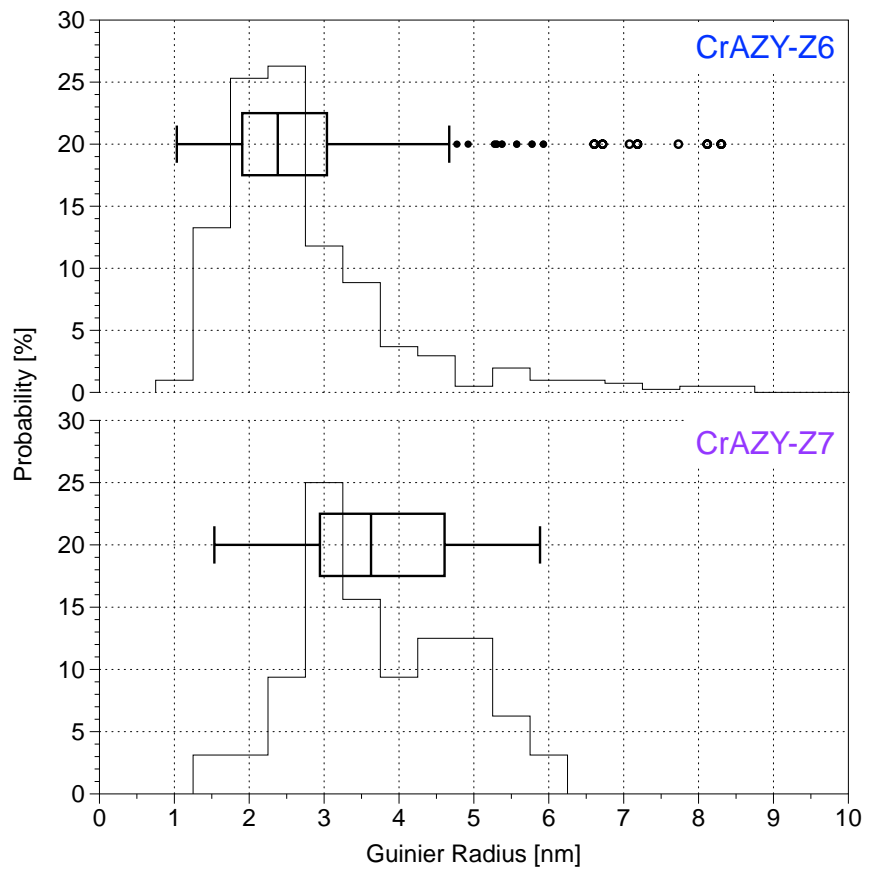

Figure 8. Graphical summaries of nanoprecipitate size distributions in the $\mathrm{Z6}$ and $\mathrm{Z7}$ tubes, following tube processing. The higher annealing temperature used to fully recrystallize the $\mathrm{Z} 7$ tube, $1,200^{\circ} \mathrm{C}$, shifted the size distribution to larger precipitate radii in comparison with Z6 due to precipitate coarsening. 
Irradiation resistance, specifically resistance to phenomena such as irradiation hardening, requires a sufficiently high density of nanometer-scale surfaces, or sinks, within the microstructure at which irraidation-induced defects can recombine. This is a difficult threshold to achieve since sink strengths in excess of $10^{16} \mathrm{~m}^{-2}$ would be required to ensure this condition [23]. This sink strength is a function of microstructural ,features such as grain size, precipitate dispersion, and disloction density - all three of which are affected by the recrystallization and rolling treatments. Although the dislocation density is still appreciably high in the $\mathrm{Z} 7$ alloy after the final tube thickness reduction rolling step, the quantitative dislocation density in both alloys is difficult to estimate, so this will be removed from the current analysis. Instead, considering a change in grain size from $\sim 650 \mathrm{~nm}$ for Z6 to $\sim 1 \mathrm{~mm}$ for Z7, the sink strength from grain boundaries almost dissapears; furthermore, the coarsened precipitate structure similarly decreases the sink strength. When these factors are considered, the sink strengths for Z6 and Z7 are calculated as $7.7 \times 10^{15} \mathrm{~m}^{-2}$ and $1.3 \times 10^{15} \mathrm{~m}^{-2}$, respectively. Therefore, the $\mathrm{Z7}$ alloy is likely not as effective at mitigating irradiation hardening as the Z6 and OR1 alloys. However it is possible that fully recrystallized ODS FeCrAl will still outperform these wrought alternatives.

The production of two additional ODS FeCrAl tubes in FY19 and FY20 allowed for the continued investigation of how thermomechanical processing can be used to optimize the material properties of the alloy system. The modified recrystallization and rolling procedure for $\mathrm{Z7}$ resulted in limited deformability, as exemplified by the circumferential cracking of the tube and the axial tube tensile tests. It is clear from the literature that a fully recrystallized microstructure will provide less anisotropy in the mechanical response of the tubes. It was also recently demonstrated that even in the recrystallized form, recent heats of ODS FeCrAl exhibit competitive creep properties in comparison with 9Cr ODS alloys [18]. This data, coupled with the limited ductility shown in previous reports on non-recrystallized CrAZY alloys, highlights the need to recrystallize future ODS FeCrAl alloys for the application of ATF cladding. Although this will adversely affect the ability of the ODS FeCrAl alloy to prevent phenomena-such as irradiation hardening, which has been the primary motivation for keeping the non-recrystallized microstructure for the CrAZY alloys in the past-it is still unclear whether the still-high number density of $(\mathrm{Y}, \mathrm{Al}, \mathrm{O})$-rich precipitates will help prevent other phenomena, such as deleterious alpha-prime precipitation [24].
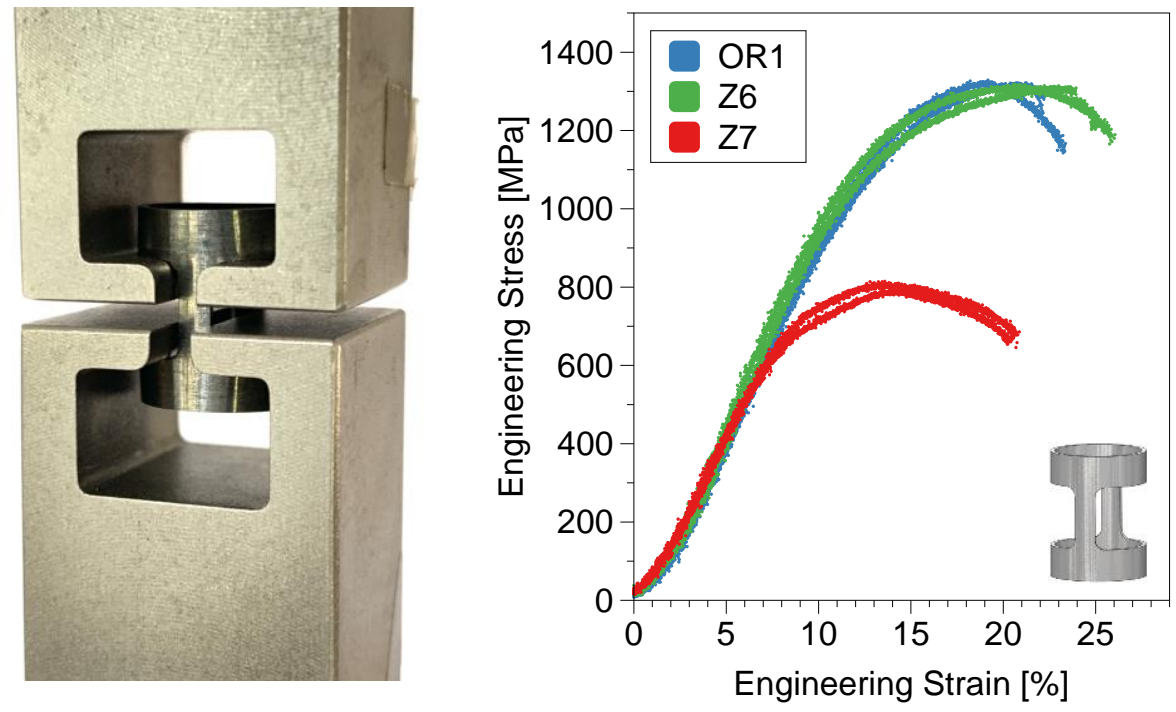

Figure 9. Axial tube tensile tests directly compare the original pilgered CrAZY-OR1 tube with the properties of the two new CrAZY tubes (Z6 and Z7). On the left, the experimental setup for the tube tensile test is provided, and on the right, engineering stress/strain curves at room temperature are overlaid for each tube. 


\section{Increasing the TRL for ODS FeCrAI}

In the original $\mathrm{FeCrAl}$ implementation plan, various research directions were highlighted, which cover realms of basic alloy science, advanced manufacturing to create thin-walled tubes, the evaluation of unirradiated and irradiated material properties for the alloy in prototypic geometries, and an understanding of in-reactor behavior in normal operating conditions and in off-normal conditions. A list of each of the primary research directions is provided in Table 3. Over the past decade, significant advances in research for wrought $\mathrm{FeCrAl}$ alloys have been made in many of these areas, and a selection of some of the pertinent research is highlighted in Table 3. The handbook of material properties for $\mathrm{FeCrAl}$ alloys [25] provides a more in-depth review of the current state-of-the-art research on the wrought FeCrAl system.

In the same wrought $\mathrm{FeCrAl}$ technology implementation plan, the original ODS FeCrAl research directions were also highlighted, which overlapped with the wrought FeCrAl objectives but initially focused more on basic alloy science due to the lower TRL that existed at the time. Since FY14, most of the work on ODS FeCrAl at ORNL has focused on alloy optimization and tube fabrication. This is reinforced by the list of applicable milestone reports presented in Table 4. These realms also included unirradiated material property evaluations with respect to oxidation and mechanical properties. There was some initial work on ODS FeCrAl weldments, but little work has been completed in this realm at ORNL on optimized Generation 2 ODS FeCrAl alloys, especially in thin-walled tube forms. Additionally, there have been initial irradiations on tensile specimens of Generation 1 ODS FeCrAl and similar irradiations on an initial ODS FeCrAl thin-walled tube manufactured in FY18. However, irradiation data on fully recrystallized ODS FeCrAl will be critical for future qualification of the alloy system.

In Table 3, a variety of references to pertinent literature sources on (1) legacy high-Cr ODS FeCrAl, (2) recently developed lower $\mathrm{Cr}$ ODS FeCrAl, and (3) wrought $\mathrm{FeCrAl}$ are listed to provide a qualitative description of the state of scientific understanding for each alloy system. This table is not a complete primer on the state-of-the-art literature on each alloy system, but it does show the overlaps that exist between legacy ODS FeCrAl development efforts and recent lower Cr ODS FeCrAl development advancements that occurred over the past decade. On the right-hand side of the table, the colors indicate where gaps in understanding exist on a qualitative level and where the current knowledge of the wrought FeCrAl system might be able to help fill in some of the gaps when trying to increase the TRL for the low$\mathrm{Cr}$ ODS FeCrAl alloy system. For example, the steam oxidation kinetics for the low-Cr ODS FeCrAl alloys developed at ORNL are identical to those seen of the wrought $\mathrm{FeCrAl}$ alloy system $[3,4,8,26]$. Additionally, recent developments of pressure resistance welding (PRW) at INL for wrought FeCrAl alloys and the ODS FeCr MA957 alloy indicate that this method might apply to ODS FeCrAl alloys also [27-31].

Although processing effects pertaining to recent developments in FY20 are discussed later in this work, it is worth noting that the work performed at ORNL coupled with parallel development efforts on different $\sim 15 \mathrm{Cr}$ ODS FeCrAl alloys in Japan [22, 32, 33] caused significant leaps in ODS FeCrAl tube processing to accomplished. Additionally, it was demonstrated that nanoprecipitate size and mechanical properties can be optimized, depending on the ball milling and thermomechanical processing temperatures used for alloy production $[10,14,21]$. 
Table 3. A selection of work to date on ODS FeCrAl in comparison with benchmarks from the previous technology implementation plan.

\begin{tabular}{|c|c|c|c|c|}
\hline Area & $\begin{array}{c}\text { Legacy ODS } \\
\text { FeCrAl } \\
\text { (PM2000/MA956) } \\
\end{array}$ & $\begin{array}{c}\text { Low Cr ODS } \\
\text { FeCrAl } \\
(10-15 \text { wt.\% Cr) }\end{array}$ & $\begin{array}{l}\text { Wrought } \\
\text { FeCrAl }\end{array}$ & $\begin{array}{c}\text { Understanding } \\
\text { for ODS } \\
\text { FeCrAl } \\
\end{array}$ \\
\hline Base material manufacturing & [34-44] & $\begin{array}{c}{[8,10-12,22,26} \\
32,33,45]\end{array}$ & {$[5,46,47]$} & \\
\hline Welding & [48-57] & N/A & {$[27,29-31]$} & \\
\hline Tube fabrication & {$[58]$} & [19] & [59-61] & \\
\hline Unirradiated material properties & {$[62-70]$} & {$[8,18,19,26]$} & {$[5,25]$} & \\
\hline Irradiated material properties & [71-74] & {$[24,75]$} & {$[6,76]$} & \\
\hline Aqueous corrosion & [77] & N/A & [78-80] & \\
\hline Fretting & N/A & N/A & [81-83] & \\
\hline Hydrogen diffusion & {$[84,85]$} & {$[86,87]$} & {$[25,80,88]$} & \\
\hline Integral fuel tests & N/A & N/A & $\mathrm{n} / \mathrm{a}$ & \\
\hline $\begin{array}{r}\text { Loss-of-coolant analysis (LOCA)/ } \\
\text { burst testing }\end{array}$ & N/A & N/A & {$[15,89,90]$} & \\
\hline Reactivity-initiated accident (RIA) & N/A & N/A & {$[91,92]$} & \\
\hline Fuel melt/relocation & N/A & N/A & N/A & \\
\hline Cladding leak-normal operation & N/A & N/A & N/A & \\
\hline High-temperature steam oxidation & {$[8,93,94]$} & {$[8,26]$} & {$[3,4]$} & \\
\hline \multicolumn{5}{|c|}{ High quality of data } \\
\hline \multicolumn{5}{|c|}{ Some data } \\
\hline \multicolumn{5}{|c|}{ Little to no data } \\
\hline
\end{tabular}


Table 4. Summary of prior milestone reports submitted in the ODS FeCrAl program.

\begin{tabular}{|c|c|c|c|}
\hline Area & $\begin{array}{c}\text { Fiscal } \\
\text { year }\end{array}$ & Description & Reports \\
\hline \multirow{7}{*}{$\begin{array}{l}\text { Base material } \\
\text { manufacturing }\end{array}$} & \multirow{2}{*}{ FY14 } & Manufacturing Gen 1 ATF ODS FeCrAl & M3FT-14OR0202272 \\
\hline & & Test base material Gen 1 ATF ODS FeCrAl & M2FT-14OR0202271 \\
\hline & \multirow{2}{*}{ FY15 } & Continue Testing of Generation 1 ATF ODS FeCrAl & M3FT-15OR0202281 \\
\hline & & Manufacturing of Gen 2 ATF ODS FeCrAl & M3FT-16OR020202091 \\
\hline & \multirow[b]{2}{*}{ FY16 } & Testing of Generation II ATF ODS FeCrAl & \multirow{3}{*}{ M3FT-16OR020202091 } \\
\hline & & $\begin{array}{l}\text { Optimization of Generation II ATF ODS FeCrAl for thin } \\
\text { tubing }\end{array}$ & \\
\hline & FY17 & Testing of optimized Generation II ATF ODS FeCrAl & \\
\hline Welding & FY14 & Initial fabrication of ODS FeCrAl laser welds & M3FT-14OR0202273 \\
\hline \multirow{12}{*}{$\begin{array}{l}\text { Tube } \\
\text { fabrication }\end{array}$} & FY14 & Produce initial MA956 thin-walled tubing & M3FT-15PN0202374 \\
\hline & \multirow{2}{*}{ FY15 } & $\begin{array}{l}\text { Produce thin walled tubing of an advanced ODS ferritic } \\
\text { steel (MA956) using pilger processing }\end{array}$ & M3FT-15PN0202371 \\
\hline & & MA-956 Tubing Process Development Report & M3FT-15PN0202373 \\
\hline & \multirow{2}{*}{ FY16 } & $\begin{array}{l}\text { Production thin plates of Generation II ATF ODS FeCrAl } \\
\text { to demonstrate manufacturability of thin tubes }\end{array}$ & $\begin{array}{l}\text { Included in } \\
\text { M3NT-18OR020202051 }\end{array}$ \\
\hline & & $\begin{array}{l}\text { Manufacturing of commercial Generation II ATF ODS } \\
\text { FeCrAl powder }\end{array}$ & M3FT-17OR020202081 \\
\hline & FY17 & $\begin{array}{l}\text { Characterization of commercial Generation II ATF ODS } \\
\text { FeCrAl powder }\end{array}$ & M3FT-17OR020202081 \\
\hline & \multirow{4}{*}{ FY18 } & $\begin{array}{l}\text { Production of thin plates of optimized Generation II ATF } \\
\text { ODS FeCrAl }\end{array}$ & \multirow{2}{*}{ M3NT-18OR020202051 } \\
\hline & & $\begin{array}{l}\text { Testing of thin plates of optimized Generation II ATF } \\
\text { ODS FeCrAl }\end{array}$ & \\
\hline & & $\begin{array}{l}\text { Manufacturing of optimized Generation II ATF ODS } \\
\text { FeCrAl thin tubes }\end{array}$ & \multirow{2}{*}{$\begin{array}{l}\text { M3NT-18OR020202051, } \\
\text { M3FT-19OR020202071 }\end{array}$} \\
\hline & & $\begin{array}{l}\text { Testing and reporting on optimized Generation II ATF } \\
\text { ODS FeCrAl thin tubes properties }\end{array}$ & \\
\hline & FY19* & $\begin{array}{l}\text { Production of Additional Optimized Generation II ATF } \\
\text { ODS FeCrAl rods for thin-walled tubes }\end{array}$ & M4FT-19OR020202074 \\
\hline & FY20* & $\begin{array}{l}\text { Characterization of two new Generation II ATF ODS } \\
\text { FeCrAl thin-walled Tubes }\end{array}$ & Included in This Work \\
\hline \multirow{4}{*}{$\begin{array}{l}\text { Irradiated } \\
\text { material } \\
\text { properties }\end{array}$} & FY15 & $\begin{array}{l}\text { Prepare rabbit capsules for Generation I ATF ODS } \\
\text { FeCrAl materials for HFIR irradiation }\end{array}$ & M3CA-15OR0202241 \\
\hline & FY16 & $\begin{array}{l}\text { Post irradiation examination of Generation I ATF ODS } \\
\text { FeCrAl }\end{array}$ & M3FT-16OR020203053 \\
\hline & FY17 & $\begin{array}{l}\text { Prepare rabbit capsules for Generation II ATF ODS } \\
\text { FeCrAl materials for HFIR irradiation }\end{array}$ & M3NT-18OR020203043 \\
\hline & FY19 & $\begin{array}{l}\text { Map radiation temperature and dose effects of optimized } \\
\text { Generation II ATF ODS FeCrAl thin tubes - rabbit } \\
\text { design }\end{array}$ & M3FT-19OR020203045 \\
\hline
\end{tabular}


Gaps pertaining to cladding behavior in reactor environments are readily apparent in Table 3 . This is not just a historical problem for ODS FeCrAl alloys but is a problem that extends to ODS FeCr alloys also because the rate limiting step for increasing the TRL level has been the inability to minimize heat-to-heat variation between extruded ODS alloys and also the inability to produce cladding of prototypic geometry for irradiation campaigns. Fortunately, there have now been two successful tube development campaigns at ORNL for both the ODS FeCr and the ODS FeCrAl, each providing tubes approximately $2 \mathrm{~m}$ long, which is approaching the $4 \mathrm{~m}$ needed for a full-length cladding tube.

These advances in tube production capabilities provide the first opportunity to significantly advance the TRL of the ODS FeCrAl alloy system in decades. To put this in perspective, the nine TRLs, which are adapted from Moorhouse [95], are outlined in Table 5 and range from basic science to the full integration of the technology in commercial applications. Even after a decade's worth of research into the new lower Cr ODS FeCrAl cladding, the equivalent TRL would only be considered between a two or three. Since tubes approaching full length have been fabricated, the primary obstacle to increasing the TRL to a fivethe equivalent to a lead test rod (LTR) irradiated in the Advanced Test Reactor-is now possible with appropriate scaling of production. Having sufficient amounts of material to perform unirradiated and irradiated burst testing for LOCA, modified burst testing to simulate an RIA, and other mechanical property evaluations will take significant lengths of tubes. Additionally, additional lengths of thin-walled optimized Generation 2 ODS FeCrAl alloys will allow for a collaboration INL and the optimization of parameters for PRW for this specific alloy class. For these reasons, if ODS FeCrAl increased in TRL, then investment must be made in the continued scaling of tube production efforts now that more data are being generated on the effects of various heat treatments on the behavior of ODS FeCrAl tubes.

Figure 10 provides a visual representation of significant milestone achievements for ODS FeCrAl alloy development as a function of time compared with the equivalent TRL outlined in Table 5. It is important to note that the timeline associated with future dates is heavily optimistic, as it doesn't take into account performance criteria for fueled rod irradiations that have not yet been defined. For example, the fracture toughness of these ODS FeCrAl alloys has not yet been systematically studied, and limits have not been defined as prerequisites for fueled tube irradiations. This is a challenge for non-Zry ATF cladding alloys, as it is probable that application of licensure criteria established for zirconium will likely not capture the true degradation or performance mechanisms of systems such as $\mathrm{FeCrAl}$, ODS FeCrAl, SiC/SiC, or other future cladding materials. Recent work on fracture toughness on unirradiated $\mathrm{FeCrAl}$ alloys $(\mathrm{C} 06 \mathrm{M}$ and $\mathrm{C} 36 \mathrm{M}$ ) indicated ductile-to-brittle transition temperatures exceeding $100^{\circ} \mathrm{C}$, indicating that the high $\mathrm{Al}$ content in these alloys is deleterious for fabricability at room temperature [75]. At present there is no defined performance criteria regarding fracture of cladding materials; it is widely appreciated that hydriding of zirconium during service will reduce its ductility, but there is no specific metric by which this reduction is correlated to reactor performance or safety. The ATF community needs to better understand this topic in order to develop more quantitative mechanical property requirements.

GE is considering using a powder metallurgical approach to fabricate wrought FeCrAl alloys in the future instead of using casting-based methods due to ingot cracking issues. This willingness to move towards a powder metallurgical route for wrought $\mathrm{FeCrAl}$, which already exhibits low fracture toughness at room temperature, does provide optimism for the possible application of the powder metallurgical ODS route for ATF cladding. Other performance criteria, such as weld strengths, burst properties, compositional control, etc. are also yet to be demonstrated, which could affect the trajectory for increasing TRL levels in the near future. 
Table 5. Summary of TRLs pertaining to the ODS FeCrAl system.

\begin{tabular}{|c|c|c|}
\hline TRL & Description & Examples \\
\hline \multirow{2}{*}{1} & \multirow{2}{*}{ Basic principles } & Fundamental studies of nucleation/growth of precipitates \\
\hline & & Fundamental alloying studies for ferritic materials \\
\hline \multirow{3}{*}{2} & \multirow{3}{*}{ Formulation of application } & Ball-milling studies for powder processing optimization \\
\hline & & Extrusions to assess general properties \\
\hline & & Corrosion studies as a function of composition \\
\hline \multirow{4}{*}{3} & \multirow{4}{*}{$\begin{array}{l}\text { Analytical and experimental proof-of- } \\
\text { concept }\end{array}$} & Fabrication of full-length tubes \\
\hline & & Demonstration of consistency in final product \\
\hline & & Mechanical and microstructural evaluation \\
\hline & & Comparative studies with wrought $\mathrm{FeCrAl}$ variants \\
\hline \multirow{3}{*}{4} & \multirow{3}{*}{ Component validation on laboratory scale } & Prototypic cladding irradiation in HFIR \\
\hline & & Burst-test validation of prototype cladding \\
\hline & & $\begin{array}{l}\text { Post-irradiation examination to validate TRL levels } 2-3 \\
\text { data }\end{array}$ \\
\hline \multirow{2}{*}{5} & \multirow{2}{*}{$\begin{array}{l}\text { Component validation in relevant } \\
\text { environment }\end{array}$} & LTR irradiation in Advanced Test Reactor \\
\hline & & Accident tests (RIA, LOCA) \\
\hline 6 & $\begin{array}{l}\text { Fully integrated prototype tested in a relevant } \\
\text { environment }\end{array}$ & Lead test assembly irradiation in Advanced Test Reactor \\
\hline 7 & System Prototype in operational environment & Lead test assembly irradiation in commercial reactor \\
\hline 8 & Commercial demonstration & Full-core demonstration in commercial reactor \\
\hline 9 & $\begin{array}{l}\text { Commercial operation in relevant } \\
\text { environment }\end{array}$ & Full replacement of Zircaloy with ODS FeCrAl \\
\hline
\end{tabular}

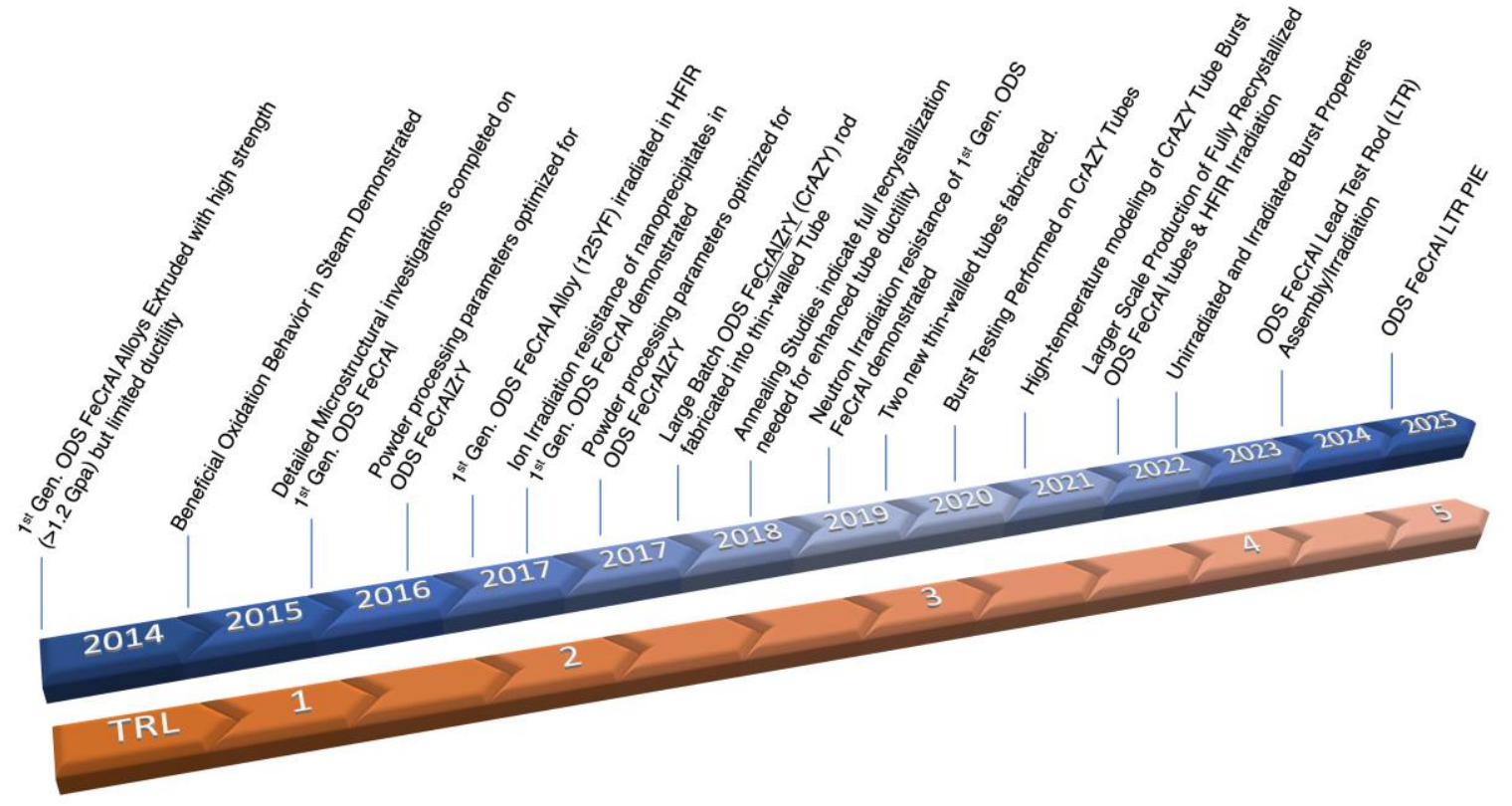

Figure 10. Visual representation of significant milestone achievements for ODS FeCrAl alloy development as a function of time (blue) in comparison with the equivalent TRL outlined in Table 5. 


\section{Conclusion}

Although the ODS FeCrAl concept is a longer term strategy for commercial vendors such as General Electric (GE) for ATF cladding, the ability to produce thin-walled cladding on length scales approaching that required to produce full-length LTR geometry coupled with GE's move to pursue powder-based manufacturing of wrought $\mathrm{FeCrAl}$ alloys make ODS FeCrAl a more viable concept for continued development. The main challenge to the TRL increase for the concept is producing enough material to pursue avenues (e.g., PRW studies, irradiation campaigns, burst/modified burst testing initiatives) to place the concept in a position to produce LTRs for irradiation in the next half decade.

FY20 work on the evaluation of two new ODS FeCrAl tubes shows the ability to produce tubes with consistent microstructure and mechanical properties based on the thermomechanical processing route used. Based on the work on these tubes, it is now possible to down-select the Fe-12Cr-6Al composition as the base composition for the CrAZY ODS alloy. In addition, studies regarding the high temperature burst and tensile properties of the recrystallized alloy are underway. Future work should focus on (1) the ability to produce full-length (4-5 m) cladding tubes of LWR-relevant dimensions and (2) the continued partnership with commercial collaborators to scale up tube production for more extensive data for sufficient unirradiated and irradiated data for quality assurance purposes.

\section{References}

[1] S.J. Zinkle, K.A. Terrani, J.C. Gehin, L.J. Ott, L.L. Snead, Accident tolerant fuels for LWRs: A perspective, Journal of Nuclear Materials 448(1-3) (2014) 374-379.

[2] K.A. Terrani, S.J. Zinkle, L.L. Snead, Advanced oxidation-resistant iron-based alloys for LWR fuel cladding, Journal of Nuclear Materials 448(1-3) (2014) 420-435.

[3] B.A. Pint, K.A. Terrani, M.P. Brady, T. Cheng, J.R. Keiser, High temperature oxidation of fuel cladding candidate materials in steam-hydrogen environments, Journal of Nuclear Materials 440(1-3) (2013) 420-427.

[4] B.A. Pint, K.A. Terrani, Y. Yamamoto, L.L. Snead, Material selection for accident tolerant fuel cladding, Metallurgical and Materials Transactions E 2(3) (2015) 190-196.

[5] Y. Yamamoto, B.A. Pint, K.A. Terrani, K.G. Field, Y. Yang, L.L. Snead, Development and property evaluation of nuclear grade wrought $\mathrm{FeCrAl}$ fuel cladding for light water reactors, Journal of Nuclear Materials 467 (2015) 703-716.

[6] K.G. Field, X. Hu, K.C. Littrell, Y. Yamamoto, L.L. Snead, Radiation tolerance of neutron-irradiated model $\mathrm{Fe}-\mathrm{Cr}-\mathrm{Al}$ alloys, Journal of Nuclear Materials 465 (2015) 746-755.

[7] S.A. Briggs, P.D. Edmondson, K.C. Littrell, Y. Yamamoto, R.H. Howard, C.R. Daily, K.A. Terrani, K. Sridharan, K.G. Field, A combined APT and SANS investigation of $\alpha$ ' phase precipitation in neutronirradiated model FeCrAl alloys, Acta Materialia 129 (2017) 217-228.

[8] B.A. Pint, S. Dryepondt, K.A. Unocic, D.T. Hoelzer, Development of ODS FeCrAl for Compatibility in Fusion and Fission Energy Applications, JOM 66(12) (2014) 2458-2466.

[9] S.N. Dryepondt, C. Massey, M.N. Gussev, K. Linton, K. Terrani, Tensile Strength and Steam Oxidation Resistance of ODS FeCrAl Sheet and Tubes, Oak Ridge National Lab.(ORNL), Oak Ridge, TN (United States), 2018.

[10] S. Dryepondt, K.A. Unocic, D.T. Hoelzer, C.P. Massey, B.A. Pint, Development of low-Cr ODS FeCrAl alloys for accident-tolerant fuel cladding, Journal of Nuclear Materials 501 (2018) 59-71. [11] S.L. Dryepondt, C.P. Massey, M.N. Gussev, Milestone Report: M3FT-17OR020202081, Production and Characterization of Large Batch FeCrAl ODS Alloy, 2017.

[12] S.N. Dryepondt, C.P. Massey, P.D. Edmondson, 2nd Gen FeCrAl ODS Alloy Development For Accident-Tolerant Fuel Cladding, Oak Ridge National Lab.(ORNL), Oak Ridge, TN (United States), 2016. 
[13] C.P. Massey, S.L. Dryepondt, P.D. Edmondson, K.A. Terrani, S.J. Zinkle, Influence of Mechanical Alloying and Extrusion Conditions on the Microstructure and Tensile Properties of Low-Cr ODS FeCrAl Alloys, Journal of Nuclear Materials 512 (2018) 227-238.

[14] C.P. Massey, S.N. Dryepondt, P.D. Edmondson, M.G. Frith, K.C. Littrell, A. Kini, B. Gault, K.A. Terrani, S.J. Zinkle, Multiscale investigations of nanoprecipitate nucleation, growth, and coarsening in annealed low-Cr oxide dispersion strengthened FeCrAl powder, Acta Materialia 166 (2019) 1-17. [15] C.P. Massey, K.A. Terrani, S.N. Dryepondt, B.A. Pint, Cladding burst behavior of Fe-based alloys under LOCA, Journal of Nuclear Materials 470 (2016) 128-138.

[16] M. Snead, L. Snead, K.A. Terrani, K.G. Field, A. Worrall, K.R. Robb, Y. Yamamoto, J. Powers, S. Dryepondt, B.A. Pint, Technology Implementation Plan ATF FeCrAl Cladding for LWR Application, ORNL/TM-2014-353, Oak Ridge National Laboratory (May 2014) (2014).

[17] Y. Yano, T. Tanno, H. Oka, S. Ohtsuka, T. Inoue, S. Kato, T. Furukawa, T. Uwaba, T. Kaito, S. Ukai, N. Oono, A. Kimura, S. Hayashi, T. Torimaru, Ultra-high temperature tensile properties of ODS steel claddings under severe accident conditions, Journal of Nuclear Materials 487 (2017) 229-237.

[18] S. Ukai, S. Kato, T. Furukawa, S. Ohtsuka, High-temperature creep deformation in FeCrAl-oxide dispersion strengthened alloy cladding, Materials Science and Engineering: A 794 (2020).

[19] S.L. Dryepondt, C.P. Massey, M.N. Gussev, K.L. Linton, K.A. Terrani, M3NT-18OR020202051: Tensile Strength and Steam Oxidation Resistance of ODS FeCrAl Sheet and Tubes, (2018).

[20] U.F. Kocks, C.N. Tomé, H.-R. Wenk, Texture and anisotropy: preferred orientations in polycrystals and their effect on materials properties, Cambridge university press1998.

[21] C.P. Massey, P.D. Edmondson, K.A. Unocic, Y. Yang, S.N. Dryepondt, A. Kini, B. Gault, K.A. Terrani, S.J. Zinkle, The effect of $\mathrm{Zr}$ on precipitation in oxide dispersion strengthened FeCrAl alloys, Journal of Nuclear Materials 533 (2020).

[22] P. Dou, A. Kimura, R. Kasada, T. Okuda, M. Inoue, S. Ukai, S. Ohnuki, T. Fujisawa, F. Abe, TEM and HRTEM study of oxide particles in an Al-alloyed high-Cr oxide dispersion strengthened steel with $\mathrm{Zr}$ addition, Journal of Nuclear Materials 444(1-3) (2014) 441-453.

[23] S.J. Zinkle, L.L. Snead, Designing Radiation Resistance in Materials for Fusion Energy, Annual Review of Materials Research 44(1) (2014) 241-267.

[24] C.P. Massey, P.D. Edmondson, K.G. Field, D.T. Hoelzer, S.N. Dryepondt, K.A. Terrani, S.J. Zinkle, Post irradiation examination of nanoprecipitate stability and $\alpha^{\prime}$ precipitation in an oxide dispersion strengthened Fe-12Cr-5Al alloy, Scripta Materialia 162 (2019) 94-98.

[25] K.G. Field, M.A. Snead, Y. Yamamoto, K.A. Terrani, Handbook on the Material Properties of FeCrAl Alloys for Nuclear Power Production Applications (FY18 Version: Revision 1), Oak Ridge National Lab.(ORNL), Oak Ridge, TN (United States), 2018.

[26] S.N. Dryepondt, K.A. Unocic, D.T. Hoelzer, B.A. Pint, Advanced ODS FeCrAl alloys for accidenttolerant fuel cladding, Oak Ridge National Lab.(ORNL), Oak Ridge, TN (United States), 2014.

[27] J. Gan, N. Jerred, E. Perez, D.C. Haggard, Laser and Pressure Resistance Weld of Thin-Wall Cladding for LWR Accident-Tolerant Fuels, Jom 70(2) (2017) 192-197.

[28] J. Gan, N.D. Jerred, E.E. Perez, B.L. Mackowiak, N. Cordes, M. Bachhav, ODS Thin-wall Cladding Joining Technique Development, Idaho National Lab.(INL), Idaho Falls, ID (United States), 2019.

[29] J. Gan, E. Perez, D. Haggard, N. Jerred, Status Report on Thin-Walled Cladding Weld Development and Test Fuel Cycle Research \& Development Advanced Fuels Campaign, INL/LTD-16-39760, 2016. [30] J. Gan, E. Perez, D. Haggard, C. Nichol, N. Jered, Report on the Development of Weld Techniques for Thin Walled Tubing Fuel Cycle Research \& Development Advanced Fuels Campaign, Inl/Ltd-1534684 (2015).

[31] J. Gan, E. Perez, N. Jerred, Status Report on Pressure Resistance Weld Development for FeCrAl Thin-Wall Cladding, Idaho National Lab.(INL), Idaho Falls, ID (United States), 2017.

[32] P. Dou, A. Kimura, R. Kasada, T. Okuda, M. Inoue, S. Ukai, S. Ohnuki, T. Fujisawa, F. Abe, S. Jiang, Z. Yang, TEM and HRTEM study of oxide particles in an Al-alloyed high-Cr oxide dispersion strengthened ferritic steel with Hf addition, Journal of Nuclear Materials 485 (2017) 189-201. 
[33] P. Dou, A. Kimura, T. Okuda, M. Inoue, S. Ukai, S. Ohnuki, T. Fujisawa, F. Abe, Effects of extrusion temperature on the nano-mesoscopic structure and mechanical properties of an Al-alloyed highCr ODS ferritic steel, Journal of Nuclear Materials 417(1-3) (2011) 166-170.

[34] C.L. Chen, Y.M. Dong, Effect of mechanical alloying and consolidation process on microstructure and hardness of nanostructured Fe-Cr-Al ODS alloys, Materials Science and Engineering: A 528(29-30) (2011) 8374-8380.

[35] Y. Chen, A. Jones, Reduction of porosity in oxide dispersion-strengthened alloys produced by powder metallurgy, Metallurgical and Materials Transactions A 32(8) (2001) 2077-2085.

[36] T. Chou, Recrystallisation behaviour and grain structure in mechanically alloyed oxide dispersion strengthened MA956 steel, Materials Science and Engineering: A 223(1-2) (1997) 78-90.

[37] T. Chou, H. Bhadeshia, Crystallographic texture in mechanically alloyed oxide dispersionstrengthened MA956 and MA957 steels, Metallurgical Transactions A 24(4) (1993) 773-779.

[38] A. Czyrska-Filemonowicz, B. Dubiel, Mechanically alloyed, ferritic oxide dispersion strengthened alloys: structure and properties, Journal of Materials Processing Technology 64(1-3) (1997) 53-64.

[39] A. Czyrska-Filemonowicz, M. Wrobel, B. Dubiel, P. Ennis, Transmission electron microscopy study of dislocation-dispersoid interaction in deformed incoloy ma956, Scripta metallurgica et materialia 32(3) (1995) 331-335.

[40] K. Dawson, S.J. Haigh, G.J. Tatlock, A.R. Jones, Nano-particle precipitation in mechanically alloyed and annealed precursor powders of legacy PM2000 ODS alloy, Journal of Nuclear Materials 464 (2015) 200-209.

[41] K. Dawson, A. Rao, G.J. Tatlock, A.R. Jones, Recovery and recrystallisation in mechanically alloyed and annealed, legacy, FeCrAlY ODS alloy precursor powders, IOP Conference Series: Materials Science and Engineering 89 (2015).

[42] B. Dubiel, W. Osuch, M. Wróbel, P. Ennis, A. Czyrska-Filemonowicz, Correlation of the microstructure and the tensile deformation of incology MA956, Journal of materials processing technology 53(1-2) (1995) 121-130.

[43] B. Dubiel, M. Wróbel, P. Ennis, A. Czyrska-Filemonowicz, Microstructure of INCOLOY MA956 after low and high temperature deformation, Scripta materialia 37(8) (1997) 1215-1220. [44] M. Klimiankou, R. Lindau, A. Möslang, J. Schröder, TEM study of PM 2000 steel, Powder Metallurgy 48(3) (2013) 277-287.

[45] P. Dou, A. Kimura, T. Okuda, M. Inoue, S. Ukai, S. Ohnuki, T. Fujisawa, F. Abe, Polymorphic and coherency transition of $\mathrm{Y}-\mathrm{Al}$ complex oxide particles with extrusion temperature in an Al-alloyed highCr oxide dispersion strengthened ferritic steel, Acta Materialia 59(3) (2011) 992-1002.

[46] M.N. Gussev, E. Cakmak, K.G. Field, Impact of neutron irradiation on mechanical performance of FeCrAl alloy laser-beam weldments, Journal of Nuclear Materials 504 (2018) 221-233.

[47] M.N. Gussev, K.G. Field, Y. Yamamoto, Design, properties, and weldability of advanced oxidationresistant FeCrAl alloys, Materials \& Design 129 (2017) 227-238.

[48] C.-L. Chen, A. Richter, R. Kögler, L.-T. Wu, Dual-beam irradiation of friction stir spot welding of nanostructured ferritic oxide dispersion strengthened alloy, Journal of Alloys and Compounds 536 (2012) S194-S199.

[49] C.L. Chen, G.J. Tatlock, A.R. Jones, Microstructural evolution in friction stir welding of nanostructured ODS alloys, Journal of Alloys and Compounds 504 (2010) S460-S466.

[50] C.L. Chen, P. Wang, G.J. Tatlock, Phase transformations in yttrium -aluminium oxides in friction stir welded and recrystallised PM2000 alloys, Materials at High Temperatures 26(3) (2014) 299-303.

[51] F. Corpace, A. Monnier, J. Grall, J.-P. Manaud, M. Lahaye, A. Poulon-Quintin, Resistance Upset Welding of ODS Steel Fuel Claddings-Evaluation of a Process Parameter Range Based on Metallurgical Observations, Metals 7(9) (2017).

[52] K. Dawson, S. Cater, G.J. Tatlock, C. Stanhope, Friction stir welding of PM2000 ODS alloy, Materials Science and Technology 30(13) (2014) 1685-1690. 
[53] E. Getto, B. Baker, B. Tobie, S. Briggs, K. Hattar, K. Knipling, Effect of friction stir welding and self-ion irradiation on dispersoid evolution in oxide dispersion strengthened steel MA956 up to 25 dpa, Journal of Nuclear Materials 515 (2019) 407-419.

[54] G. J. Tatlock, K. Dawson, T. Boegelein, K. Moustoukas, A. R. Jones, High resolution microstructural studies of the evolution of nano-scale, yttrium-rich oxides in ODS steels subjected to ball milling, selective laser melting or friction stir welding, Materials Today: Proceedings 3(9) (2016) 30863093.

[55] F. Legendre, S. Poissonnet, P. Bonnaillie, L. Boulanger, L. Forest, Some microstructural characterisations in a friction stir welded oxide dispersion strengthened ferritic steel alloy, Journal of Nuclear Materials 386-388 (2009) 537-539.

[56] M.H. Mathon, V. Klosek, Y. de Carlan, L. Forest, Study of PM2000 microstructure evolution following FSW process, Journal of Nuclear Materials 386-388 (2009) 475-478.

[57] V. Krishnardula, V. Krishnardula, D. Clark, T. Totemeier, Joining Techniques For Ferritic ODS Alloys, Idaho National Laboratory (INL), 2005.

[58] G. Pimentel, C. Capdevila, M.J. Bartolomé, J. Chao, M. Serrano, A. García-Junceda, M. Campos, J.M. Torralba, J. Aldazábal, Advanced FeCrAl ODS steels for high-temperature structural applications in energy generation systems, Revista de Metalurgia 48(4) (2012) 303-316.

[59] Y. Yamamoto, Z. Sun, B.A. Pint, K.A. Terrani, Optimized Gen-II FeCrAl cladding production in large quantity for campaign testing, Oak Ridge: Oak Ridge National Laboratory (2016).

[60] Y. Yamamoto, Development and quality assessments of commercial heat production of ATF FeCrAl tubes, Oak Ridge National Lab.(ORNL), Oak Ridge, TN, United States (2015).

[61] R.B. Rebak, S. Huang, M. Schuster, S.J. Buresh, E.J. Dolley, Fabrication and Mechanical Aspects of Using $\mathrm{FeCrAl}$ for Light Water Reactor Fuel Cladding, Pressure Vessels and Piping Conference, American Society of Mechanical Engineers, 2019, p. V06BT06A010.

[62] J.H. Schneibel, M. Heilmaier, W. Blum, G. Hasemann, T. Shanmugasundaram, Temperature dependence of the strength of fine- and ultrafine-grained materials, Acta Materialia 59(3) (2011) 13001308.

[63] C. Capdevila, M.K. Miller, J. Chao, Phase separation kinetics in a Fe-Cr-Al alloy, Acta Materialia 60(12) (2012) 4673-4684.

[64] C. Capdevila, M.K. Miller, I. Toda, J. Chao, Influence of the $\alpha-\alpha^{\prime}$ phase separation on the tensile properties of Fe-base ODS PM 2000 alloy, Materials Science and Engineering: A 527(29-30) (2010) 7931-7938.

[65] J. Chao, C. Capdevila, Anisotropy in Mechanical Properties and Fracture Behavior of an Oxide Dispersion Fe20Cr5Al Alloy, Metallurgical and Materials Transactions A 45(9) (2014) 3767-3780.

[66] J. Chao, C. Capdevila, M. Serrano, A. Garcia-Junceda, J.A. Jimenez, M.K. Miller, Effect of $\alpha-\alpha^{\prime}$ phase separation on notch impact behavior of oxide dispersion strengthened (ODS) Fe20Cr5Al alloy, Materials \& Design 53 (2014) 1037-1046.

[67] J. Chao, C. Capdevila, M. Serrano, A. Garcia-Junceda, J.A. Jimenez, G. Pimentel, E. UronesGarrote, Notch Impact Behavior of Oxide-Dispersion-Strengthened (ODS) Fe20Cr5Al Alloy, Metallurgical and Materials Transactions A 44(10) (2013) 4581-4594.

[68] J. Chao, J. González-Carrasco, J. Ibañez, M. Escudero, G. González-Doncel, Effects of the alumina scale on the room-temperature tensile behavior of preoxidized MA 956, Metallurgical and Materials Transactions A 27(12) (1996) 3809-3816.

[69] J. Han Kim, T. Sang Byun, D.T. Hoelzer, Stress relaxation behavior of nanocluster-strengthened ferritic alloy at high temperatures, Journal of Nuclear Materials 425(1-3) (2012) 147-155.

[70] U. Hangen, C.-L. Chen, A. Richter, Mechanical Characterization of PM2000 Oxide-DispersionStrengthened Alloy by High Temperature Nanoindentation, Advanced Engineering Materials 17(11) (2015) 1683-1690.

[71] J. Chen, W. Hoffelner, Irradiation creep of oxide dispersion strengthened (ODS) steels for advanced nuclear applications, Journal of Nuclear Materials 392(2) (2009) 360-363. 
[72] J. Chen, P. Jung, M.A. Pouchon, T. Rebac, W. Hoffelner, Irradiation creep and precipitation in a ferritic ODS steel under helium implantation, Journal of Nuclear Materials 373(1-3) (2008) 22-27.

[73] J. Chen, M.A. Pouchon, A. Kimura, P. Jung, W. Hoffelner, Irradiation creep and microstructural changes in an advanced ODS ferritic steel during helium implantation under stress, Journal of Nuclear Materials 386-388 (2009) 143-146.

[74] D. Gelles, Microstructural examination of commercial ferritic alloys at $200 \mathrm{dpa}$, Journal of nuclear materials 233 (1996) 293-298.

[75] X. Chen, K.G. Field, D. Zhang, C. Massey, J. Robertson, K. Linton, A. Nelson, Post-Irradiation Fracture Toughness Characterization of Generation II FeCrAl Alloys, Oak Ridge National Lab.(ORNL), Oak Ridge, TN (United States), 2019.

[76] K.G. Field, K.C. Littrell, S.A. Briggs, Precipitation of $\alpha^{\prime}$ in neutron irradiated commercial FeCrAl alloys, Scripta Materialia 142 (2018) 41-45.

[77] G. Korb, M. Rühle, H.-P. Martinz, New iron-based ODS-superalloys for high demanding applications, ASME 1991 International Gas Turbine and Aeroengine Congress and Exposition, American Society of Mechanical Engineers, 1991, pp. V005T12A015-V005T12A015.

[78] S.S. Raiman, K.G. Field, R. Rebak, Y. Yamamoto, K. Terrani, Hydrothermal Corrosion of Second Generation FeCrAl Alloys in Boiling Water Reactor Conditions, Oak Ridge National Lab.(ORNL), Oak Ridge, TN (United States), 2019.

[79] K.A. Terrani, B.A. Pint, Y.J. Kim, K.A. Unocic, Y. Yang, C.M. Silva, H.M. Meyer, R.B. Rebak, Uniform corrosion of FeCrAl alloys in LWR coolant environments, Journal of Nuclear Materials 479 (2016) 36-47.

[80] R.B. Rebak, Y.-J. Kim, Hydrogen diffusion in $\mathrm{FeCrAl}$ alloys for light water reactors cladding applications, Pressure Vessels and Piping Conference, American Society of Mechanical Engineers, 2016, p. V06BT06A010.

[81] T. Winter, R.W. Neu, P.M. Singh, L.E. Kolaya, D. Vizoso, C.S. Deo, Coefficient of friction evolution with temperature under fretting wear for $\mathrm{FeCrAl}$ fuel cladding candidate, Journal of Nuclear Materials 520 (2019) 140-151.

[82] T.C. Winter, R.W. Neu, P.M. Singh, L.E. Kolaya, C.S. Deo, Fretting wear comparison of cladding materials for reactor fuel cladding application, Journal of Nuclear Materials 508 (2018) 505-515. [83] Y.-H. Lee, T.S. Byun, A comparative study on the wear behaviors of cladding candidates for accident-tolerant fuel, Journal of Nuclear Materials 465 (2015) 857-865.

[84] E. Malitckii, Y. Yagodzinskyy, M. Ganchenkova, S. Binyukova, H. Hänninen, R. Lindau, P. Vladimirov, A. Moeslang, Comparative study of hydrogen uptake and diffusion in ODS steels, Fusion Engineering and Design 88(9-10) (2013) 2607-2610.

[85] D. Sun, J. Ding, Y. Yang, P. Zhang, J. Zhao, First-principles investigation of hydrogen behavior in different oxides in ODS steels, International Journal of Hydrogen Energy 44(31) (2019) 17105-17113. [86] X. Hu, L. Tan, K. Wang, C.P. Massey, D.T. Hoelzer, Y. Katoh, Deuterium retention in advanced steels for fusion reactor structural application, Journal of Nuclear Materials 516 (2019) 144-151.

[87] Y. Urabe, K. Hashizume, T. Otsuka, K. Sakamoto, Tritium Permeation through Ce-ODS Steel, Fusion Science and Technology 76(4) (2020) 392-397.

[88] X. Hu, K.A. Terrani, B.D. Wirth, L.L. Snead, Hydrogen permeation in FeCrAl alloys for LWR cladding application, Journal of Nuclear Materials 461 (2015) 282-291.

[89] K.A. Gamble, T. Barani, D. Pizzocri, J.D. Hales, K.A. Terrani, G. Pastore, An investigation of $\mathrm{FeCrAl}$ cladding behavior under normal operating and loss of coolant conditions, Journal of Nuclear Materials 491 (2017) 55-66.

[90] M.N. Gussev, T.S. Byun, Y. Yamamoto, S.A. Maloy, K.A. Terrani, In-situ tube burst testing and high-temperature deformation behavior of candidate materials for accident tolerant fuel cladding, Journal of Nuclear Materials 466 (2015) 417-425.

[91] M.N. Cinbiz, B. Garrison, R.R. Lowden, R.G. Sitterson, K. Linton, Progress Report on Modified Burst Testing and Alternative Test Methodologies, Oak Ridge National Lab.(ORNL), Oak Ridge, TN (United States), 2019. 
[92] M.N. Cinbiz, N. Brown, R.R. Lowden, K. Linton, K.A. Terrani, RIA simulation tests using driver tube for ATF cladding, Oak Ridge National Lab.(ORNL), Oak Ridge, TN (United States), 2017.

[93] H. Al-Badairy, G.J. Tatlock, The influence of the moisture content of the atmosphere on alumina scale formation and growth during high temperature oxidation of PM2000, Materials at High Temperatures 17(1) (2014) 133-137.

[94] S. Dryepondt, A. Rouaix-Vande Put, B.A. Pint, Effect of $\mathrm{H} 2 \mathrm{O}$ and $\mathrm{CO} 2$ on the Oxidation Behavior and Durability at High Temperature of ODS-FeCrAl, Oxidation of Metals 79(5) (2013) 627-638. [95] D.J. Moorhouse, Detailed Definitions and Guidance for Application of Technology Readiness Levels, Journal of Aircraft 39(1) (2002) 190-192. 
This page is intentionally left blank. 